\title{
The Continuous Culture of Rotifer Brachionus plicatilis with Sea water
}

\author{
Jai Gopal Sharma ${ }^{1}$, Reiji Masuda ${ }^{2}$, Masaru Tanaka ${ }^{3}$ and Rina Chakrabarti ${ }^{4 \star}$ \\ ${ }^{1}$ Department of Biotechnology, Delhi Technological University, Bawana Road, Delhi 110042, India \\ ${ }^{2}$ Fisheries Research Station, Kyoto University, Nagahama, Maizuru 625-0086, Japan \\ ${ }^{3}$ Division of Applied Biosciences, Graduate School of Agriculture, Kyoto University, Kyoto 606-8502, Japan \\ ${ }^{4}$ Department of Zoology, University of Delhi, Delhi 110 007, India
}

\section{Article Info}

\author{
*Corresponding author: \\ Rina Chakrabarti \\ Department of Zoology \\ University of Delhi \\ Delhi \\ India
}

Email: aquaresearchlab@yahoo.co.in

\section{Received: August 3, 2018 \\ Accepted: August 16, 2018 \\ Published: August 22, 2018}

Citation: Sharma JG, Masuda R, Tanaka M, Chakrabarti R. The Continuous Culture of Rotifer Brachionus plicatilis with Sea water. Madridge J Aquac Res Dev. 2018; 2(1): 40-42. doi: 10.18689/mjard-1000108

Copyright: @ 2018 The Author(s). This work is licensed under a Creative Commons Attribution 4.0 International License, which permits unrestricted use, distribution, and reproduction in any medium, provided the original work is properly cited.

Published by Madridge Publishers

\begin{abstract}
Rotifers are the favourable live food for fish larvae. A steady supply of rotifers is key factor for successful larviculture. The present study aimed to develop a simple zootechnique to reduce labour for high density culture of rotifers. Brachionus plicatilis (inoculation density: $737 \pm 80$ organisms/ml) were cultured in 100 I plastic, cylindrical tanks using $100 \%$ sea water. The water was renewed on every $5^{\text {th }}$ day of culture without any further exchange of water in between. The culture was continued for 32 days. Rotifers were fed with Chlorella spp. at the rate of $200 / \mathrm{ml}$, twice daily. Total $1059 \pm 25$ organisms $/ \mathrm{ml}$ was recorded on day- 1 of culture. Significantly $(P<0.05)$ higher number of rotifers was recorded on day-4 compared to day-1. A $13.12 \%$ higher density was recorded on day- 8 compared to day- 4 ; the population was reduced $5 \%$ on day- 12 compared to the previous day. Then the number of rotifer increased gradually. Significantly $(P<0.05)$ higher number of rotifer $(1798 \pm 25 / \mathrm{ml})$ was recorded on day-20 compared to the remaining culture period. A gradual decreasing trend was found thereafter. Still the number of organism was more than $1000 / \mathrm{ml}$.
\end{abstract}

Keywords: Brachionus plicatilis; Chlorella spp; Exchange of water; Production.

\section{Introduction}

The mixohaline rotifer Brachionus spp. (both $L$ type and $S$ type) is most commonly used live food in marine larviculture. Rotifers are important forage zooplankton as their size is appropriate for larval fish as a starter food during early exogenous feeding [1]. In Japan, an average hatchery requires 20 billion rotifers/day [2], [3]. Various culture techniques have been used for the production of this important live food organism. The production of Brachionus plicatilis ( $\mathrm{L}$ type) is labour intensive. This species requires intensive care. The growth rate of $L$ type rotifer tends to decrease above $26^{\circ} \mathrm{C}$, whereas the $\mathrm{S}$ type rotifer (Brachionus rotundiformis) grows well even at $28^{\circ} \mathrm{C}$ or higher temperature. In Japan, most of the hatcheries use $S$ type rotifer during summer when the temperature is $>28^{\circ} \mathrm{C}$. Usually, the concentration of rotifer in the culture system is around 100 organisms/ml, but the concentration may reach more than 1000 organisms/ml [4]. Various algae like Chlorella, Scenedesmus, Nanochloropsis, Isochrysis, Monochrysis, Dunaliella, etc. are used as food for Brachionus plicatilis. Brachionus plicatilis are fed with Dunaliella sp. at the salinity of 25-33 ppt and it is found that crowding up to 200 organisms $/ \mathrm{ml}$ has no impact on reproduction [5]. Hirata [6] observes that the density of rotifer fed with microalgae and yeast can be maintained up to 500 organisms $/ \mathrm{ml}$. Brachionus rubens are grown on Scenedesmus at the density of 500 organisms $/ \mathrm{ml}$ [7]. Brachionus plicatilis fed 
with Chlorella and baker's yeast shows a growth efficiency of $25.4 \%$ [8]. Rotifers are batch-cultured at density of 100 to 300/ $\mathrm{ml}$ on a diet of microalgae and baker's yeast; higher density of 300 to 700 organisms/ml may be grown by feeding with commercial diet Culture Selco and Rotimac [9].

The production of rotifers is influenced by various factors like temperature, salinity, quality and quantity of food, crowding etc. [5]. The instability of rotifer mass culture is an important unresolved problem. In European hatcheries, the major problem of rotifer culture is the unpredictability of production [10]. Cultures occasionally crash due to unexplained reasons [11]. Besides scarcity of food during crowding, high level of unionized ammonia may be harmful to rotifers.

In the traditional Japanese rotifer culture, a combination of marine and freshwater (70: 30) is used. The water temperature is usually maintained at $20^{\circ} \mathrm{C}$ under high aeration condition. Once the culture has been started, there is exchange of water in the following sequence: 30,50 and $70 \%$ on days 2, 3 and 4. On fifth day, a fresh culture starts with $100 \%$ new water. Rotifers are fed with Chlorella spp. A piece of mat has been used for removal of dead algae and organic debris; the mat is cleaned every day. The density of rotifers is maintained around 400-500 organisms/l to achieve sustainable production. This is a labour intensive method.

The present investigation aims to develop a simple zootechnique for the production of Brachionus plicatilis with reduced labour and water exchange. Maintenance of higher density of organisms is also other objective of the study. This modified technique may attract aquaculturists for its simplicity, easy maintenance and higher production.

\section{Methods}

Brachionus plicatilis was cultured at Maizuru Fisheries Research Station, Kyoto University in 100 I plastic, cylindrical tanks using $100 \%$ sea water. This strain has been cultured for larval rearing at Fisheries Research Station since long time. The inoculation density was $737 \pm 80$ organisms/ml. Three replicates were used for the study. The culture tanks were cleaned on every $5^{\text {th }}$ day (day-5) and were filled with $100 \%$ fresh sea water. The mat used for the removal of algae was cleaned on every other day. Rotifers were fed with Chlorella spp. at the rate of 200 algae/ml twice daily at 8.00 a.m. and 5.00 p.m. The culture was continued for 32 days. Water quality parameters like temperature, $\mathrm{pH}$, salinity and dissolved oxygen were monitored at regular interval. Data were compiled as means \pm S.E. All data were analyzed using oneway analysis of variance (ANOVA). Statistical significance was accepted at $P<0.05$ level.

\section{Results}

The abundance of Brachionus plicatilis was recorded as $1059 \pm 25$ organisms/ml on day- 1 after inoculation. The number of rotifers gradually increased. Significantly $(P<0.05)$ higher (17.28\%) number of rotifers was recorded on day-4 compared to day-1. The density of rotifer was $13.12 \%$ higher on day-8 compared to the density found on day-4. A $5 \%$ reduced rotifer number was recorded on day-12 of culture (Fig. 1). Significantly $(P<0.05)$ higher number of rotifers was recorded on day-16.

Figure 1. Production of Brachionus plicatilis during 32 days of culture

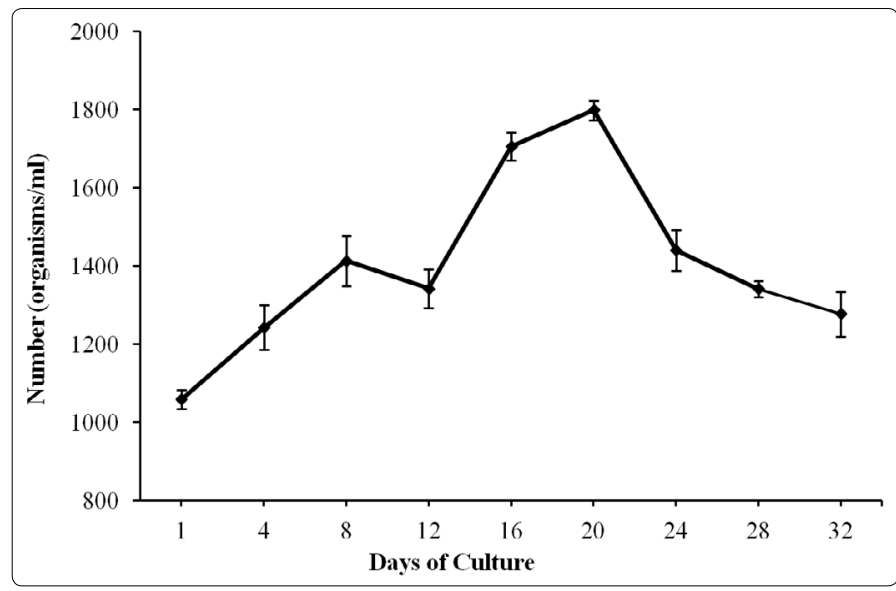

This rotifer density was $21.27 \%$ higher on day-16 compared to day-12. Then the number increased gradually. Significantly $(P<0.05)$ higher number of rotifers was recorded on day-20 compared to the rest of the culture period. Then a gradual decreasing trend was found. On day-24, the number of rotifer was significantly $(P<0.05)$ lower compared to day-20. The number of organisms further reduced and the number was $9.32 \%$ reduced on day-28 compared to day- 24 . On day-32, Brachionus plicatilis density was 5\% lower compared to day-28. Still this number was significantly $(P<0.05)$ higher compared to day-1. The number of Brachionus plicatilis was always above $1000 / \mathrm{ml}$. This is most interesting to record that there was no crash of culture during the entire study period. There was no significant $(P>0.05)$ difference in water quality parameters among replicates during the culture period (Table 1).

Table 1. Water quality parameters found during the culture of Brachionus plicatilis

\begin{tabular}{|c|c|c|}
\hline Parameter & Range & Mean \pm SE \\
\hline Temperature $\left({ }^{\circ} \mathrm{C}\right)$ & $19.2-20.2$ & $19.72 \pm 0.23$ \\
\hline Dissolved oxygen $(\mathrm{mg} / \mathrm{l})$ & $4.28-5.64$ & $5.01 \pm 0.28$ \\
\hline Salinity $(\mathrm{ppt})$. & $32.8-34.1$ & $33.6 \pm 0.30$ \\
\hline
\end{tabular}

\section{Discussion}

The present culture technique of rotifer was different from the traditional Japanese rotifer culture. Unlike traditional culture, cent percent sea water was used in the present study and there was no exchange of water. This is very useful for farmers; they have not to depend on freshwater. The tanks were cleaned on every $5^{\text {th }}$ day and mat was cleaned on alternate day. This modified method saved manpower. Lavens and Sorgeloos [12] reported that Brachionus plicatilis were cultured (starting density $200 / \mathrm{ml}$ ) with diluted sea water (25 ppt) at $25^{\circ} \mathrm{C}$. Rotifers were fed with small amount of Culture Selco at I $\mathrm{h}$ intervals and the number of rotifers was $600 / \mathrm{ml}$ after four days in Europe. In a high density cultivation of Brachionus, Nannochloropsis was supplemented with concentrated baker's yeast and yeast containing fish oil. Freshwater Chlorella was 
used with $B_{12}$ supplementation. Using this system average 1000 rotifers/ml was obtained in Japan [12]. Suantika et al. [13] reported that daily $100 \%$ exchange of water enhanced the duration of culture period up to one week without any positive effect on the production of rotifer. In recirculating system, Brachionus plicatilis were cultured at three stocking densities of 3000,5000 and 7000 individual/ml; a reliable production of 2.2 billion rotifers was obtained on daily basis during 3 weeks of culture [14].

In a 110 days continuous culture of $B$. rotundiformis (S-type) and B. plicatilis (L-type), Chlorella vulgaris was used as food and the production was $3000-6000$ orgamisms/ml and $1100-2200$ organisms/ml for S-type and L-type, respectively. The water temperature was $24^{\circ} \mathrm{C}$ (for L-type) and $30^{\circ} \mathrm{C}$ (for S-type); the salinity was 20 ppt [15]. In the present study, the density of Brachionus plicatilis ranged from 1059 - 1798 organisms/l during 32 days culture period. The water temperature and salinity ranged from 19.2 - 20.2 and 32.8 - 34.1 ppt respectively. In high density culture of rotifer, low dissolved oxygen, foaming separation and $\mathrm{NH}_{3}$ were inhibitory factors. Supply of oxygen in the culture system may help to overcome these problems [15]. In the present study, dissolved oxygen level ranged from $4.28-5.64 \mathrm{mg} / \mathrm{l}$ with an average value of $5.01 \pm 0.28 \mathrm{mg} / \mathrm{l}$. The water quality parameters in the present study were conducive for the culture for Brachionus plicatilis.

The present technique of rotifer culture has some advantages over the traditional culture method and the sophisticated culture techniques like recirculating culture. This is very simple. Rotifers were fed with Chlorella spp. and sea water was directly used without any dilution. Culture water was renewed only on every $5^{\text {th }}$ day. The density of rotifers was obtained within the range of earlier study [16]. Therefore, this technique is less expensive in terms of price and labour.

\section{Acknowledgement}

This research was a part of a research fellowship funded by Japanese Government to Dr. Jai Gopal Sharma. Authors are thankful to the staff of Maizuru Fisheries Research Station, Maizuru and Kyoto University. Japan.

\section{References}

1. Battaglene S, Purser J, Hart P, Morehead D. Priorities for live feed production and research in Tasmania. In: Hatchery Feeds: Proceedings of a Workshop held in Cairns. 2000; 4(2): 9-10.

2. Candreva $P$, Dhert $P$, Novelli $A$, Brissi $D$. Potential gains through alimentation nutrition improvements in the hatchery. In: Chatain B, Sargalia M, Sweetman J, Lavens P, eds, Seabass and Seabream Culture: Problems and Prospects. An International Workshop, 16-18 October 1996, Verona, Italy, vol. 388. European Aquaculture Society, 148-159.

3. Fu $Y$, Hada H, Yamashita T, Yoshida $Y$, et al. Development of continuous culture system for stable mass production of the marine rotifer Brachionus. Hydrobiologia. 1997; 358: 145-151.

4. Fushimi T. Systemizing large scale culture methods. In: Fukusho K, Hirayama K, eds., The First Live Feed Brachionus plicatilis. Koseisha Koseikaku, Tokyo, 1989; 118-134.

5. Groeneweg J, Schluter M. Mass production of freshwater rotifers on liquid wastes. II. Mass production of Brachionus rubens Ehrenberg 1838 in the effluent of high rate algal ponds used for the treatment of piggery waste. Aquaculture. 1981; 25(1): 17-24. doi: 10.1016/0044-8486 (81)90095-8

6. Hirata H. Rotifer culture in Japan. In: Styczynska-Jurewicz E, Backiel T, Jaspers E, Persoone G, eds., European Mariculture Society Special Publication 1979; No. 4, Bredene, Belgium, 361-375.

7. James CM, Bou-Abbas M, Al-Khars AM, et al. Production of rotifer Brachionus plicatilis for aquaculture in Kuwait. Hydrobiologia. 1983; 104(1): 77-84. doi: 10.1007/BF00045955

8. Lavens $P$, Sorgeloos P. Manual on the production and use of live food for aquaculture. Fisheries Technical Paper, 1996; Vol. 361. Food and Agricultural Organization of the United Nations, Rome, 379.

9. Lubzens E, Sagie G, Minkoff G, Meragelman E, et al. Rotifers Brachionus plicatilis improve growth rate of carp (Cyprinus carpio) larvae. Bamidgeh. 1984; 36(1): 41-46.

10. Maeda M. Microbial Processes in Aquaculture. Biocreate Press, UK and Japan, 1999

11. Skliris GP, Richards RH. Assessment of the susceptibility of brine shrimp Artemia salina and rotifer Brachionus plicatilis to experimental nodavirus infections. Aquaculture. 1998; 169(1): 133-141. doi: 10.1016/S0044-8486(98)00330-5

12. Suantika G, Dhert P, Nurhudah M, Sorgeloos P. High-density production of the rotifer Brachionus plicatilis in a recirculation system: consideration of water quality, zootechnical and nutritional aspects. Aquacult Eng. 2000; 21(3): 201-213. doi: 10.1016/S0144-8609(99)00031-X

13. Suantika G, Dhert $P$, Sweetman $E$, et al. Technical and economical feasibility of a rotifer recirculating system. Aquaculture. 2003; 227(1): 173-189. doi: 10.1016/ S0044-8486(03)00502-7

14. Theilacker GH, McMaster MF. Mass culture of the rotifer Brachionus plicatilis and its evaluation as a food for larval anchovies. Marine Biology. 1971; 10(2): 183-188. doi: 10.1007 / BF00354834

15. Yoshimura K, Usuki K, Yoshimatsu T, et al. Recent development of a high density mass culture system for the rotifer Brachionus rotundiformis Tschugunoff. Hydrobiologia. 1997; 358(1): 139-144. doi: 10.1023/A:1003169414996

16. Fu Y, Hada A., Yamashita T, Yoshida Y, Hino A. Development of a continuous culture system for stable mass production of the marine rotifer Brachionus. Hydrobiologia. 1997; 358: (1): 145-151. doi: 10.1023/A:1003117430926 